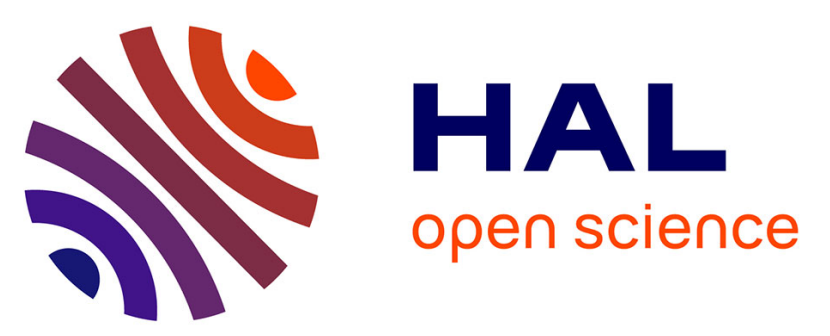

\title{
Middle-late Miocene rapid exhumation of the southern Qilian Shan and implications for propagation of the Tibetan Plateau
}

Qingquan Meng, Chunhui Song, Junsheng Nie, Chuan Liu, Pengju He, Fangbin Liu, Lin Li

\section{To cite this version:}

Qingquan Meng, Chunhui Song, Junsheng Nie, Chuan Liu, Pengju He, et al.. Middle-late Miocene rapid exhumation of the southern Qilian Shan and implications for propagation of the Tibetan Plateau. Tectonophysics, 2020, 774, pp.228279. 10.1016/j.tecto.2019.228279 . insu-02371699

\section{HAL Id: insu-02371699 \\ https://hal-insu.archives-ouvertes.fr/insu-02371699}

Submitted on 20 Nov 2019

HAL is a multi-disciplinary open access archive for the deposit and dissemination of scientific research documents, whether they are published or not. The documents may come from teaching and research institutions in France or abroad, or from public or private research centers.
L'archive ouverte pluridisciplinaire HAL, est destinée au dépôt et à la diffusion de documents scientifiques de niveau recherche, publiés ou non, émanant des établissements d'enseignement et de recherche français ou étrangers, des laboratoires publics ou privés. 


\section{Journal Pre-proof}

Middle-late Miocene rapid exhumation of the southern Qilian

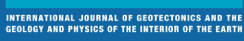

Shan and implications for propagation of the Tibetan Plateau

Qingquan Meng, Chunhui Song, Junsheng Nie, Chuan Liu, Pengju He, Fangbin Liu, Lin Li

PII: $\quad$ S0040-1951(19)30394-4

DOI: $\quad$ https://doi.org/10.1016/j.tecto.2019.228279

Reference: $\quad$ TECTO 228279

To appear in: Tectonophysics

Received date: $\quad 22$ April 2019

Revised date: $\quad 6$ November 2019

Accepted date: $\quad 11$ November 2019

Please cite this article as: Q. Meng, C. Song, J. Nie, et al., Middle-late Miocene rapid exhumation of the southern Qilian Shan and implications for propagation of the Tibetan Plateau, Tectonophysics(2018), https://doi.org/10.1016/j.tecto.2019.228279

This is a PDF file of an article that has undergone enhancements after acceptance, such as the addition of a cover page and metadata, and formatting for readability, but it is not yet the definitive version of record. This version will undergo additional copyediting, typesetting and review before it is published in its final form, but we are providing this version to give early visibility of the article. Please note that, during the production process, errors may be discovered which could affect the content, and all legal disclaimers that apply to the journal pertain.

(C) 2018 Published by Elsevier. 


\section{Middle-late Miocene rapid exhumation of the southern Qilian Shan and implications for propagation of the Tibetan Plateau}

Qingquan Meng ${ }^{\mathrm{a}}$, Chunhui Song ${ }^{\mathrm{a}, *}$, Junsheng Nie ${ }^{\mathrm{b}}$, Chuan Liu ${ }^{\mathrm{c}}$, Pengju He ${ }^{\mathrm{a}}$, Fangbin Liu ${ }^{\mathrm{b}}$, Lin $\mathrm{Li}^{\mathrm{d}}$

${ }^{a}$ School of Earth Sciences \& Key Laboratory of Mineral Resources in Western China (Gansu Province), Lanzhou University, Lanzhou 730000, China

${ }^{\mathrm{b}}$ Key Laboratory of Western China's Environmental Systems (Ministry of Education) \& College of Earth and Environmental Sciences, Lanzhou University, Lanzhou 730000, China

${ }^{c}$ College of Geographical Sciences, Southwest University, Chongqing 400715, China

${ }^{\mathrm{d}}$ Géosciences, Université de Rennes 1, Rennes 35700, France

*Corresponding author at: Guanyun Building, No. 222 South Tianshui Road, Lanzhou 730000, Gansu Province, China. E-mail address: songchh@1zu.edu.cn (C. Song).

Declarations of interest: none 


\begin{abstract}
The northeastern Tibetan Plateau is a key place to test several contrasting tectonic models regarding uplift of the plateau. However, our understanding of the Cenozoic deformation history of the northeastern Tibetan Plateau is incomplete, preventing a clear understanding of the uplift and deformation mechanisms of this plateau. Here, we present new apatite (UTh)/He ages from the hanging wall of the Qaidam Shan fault, which lies on the southern margin of the Qilian Shan. Our results reveal a phase of rapid exhumation during 15-10 Ma driven by thrusting accompanied by southward growth of the Qilian Shan. A review of the literature reveals that this phase of tectonic deformation is widespread in the northeastern Tibetan Plateau and some recent studies suggest $\sim 25-20$ Ma onset of sediment accumulation in the northern Qaidam Basin bounding the Qilian Shan. These results challenge models arguing for early deformation of northeastern margin of the Tibetan Plateau.
\end{abstract}

Keywords: Cenozoic, Rapid Exhumation, (U-Th)/He Thermochronology, Qilian Shan, Tibetan Plateau.

\title{
1 Introduction
}

The India-Asia collision is arguably the most profound tectonic event of the Cenozoic (Rowley et al., 1996). This collision has caused the formation of the Tibetan Plateau since the early Cenozoic (DeCelles et al., 2014; Hu et al., 2016). Different lines of evidence imply that the Indian Plate has moved $\sim 2500 \mathrm{~km}$ northward relative to Asia since the collision (Besse et al., 1984; Patriat and Achache, 1984; Tapponnier et al., 1990), causing intense deformation of the Asian Plate. Thus, the Tibetan Plateau can serve as a natural laboratory for understanding continent-continent collision, which can have dramatic effects on the environment, climate, and ecosystem of the surrounding area and beyond. Many contrasting mechanisms for Tibetan Plateau uplift have been proposed over the last few decades. For example, some 
models suggest that uplift of the Tibetan Plateau occurred progressively northward (Tapponnier et al., 1990, 2001; Burchfiel et al., 1991). By contrast, others indicate that deformation reached the northern margin of the plateau soon after the India-Asia collision (Yin et al., 2002, 2008; Clark et al., 2010; Fang et al., 2013; Yuan et al., 2013). Thus, clarifying the deformation history of the northern margin of the Tibetan Plateau could test the validity of these models.

The Qilian Shan is located in the northeastern Tibetan Plateau and initially formed in the Caledonian (Yin and Harrison, 2000; Xiao et al., 2009). During the Cenozoic, faults were reactivated, resulting in the formation of the modern Qilian Shan (Yin et al., 2002, 2008; Fang et al., 2007, 2013). The Qilian Shan is regarded as an area that accommodates deformation on the northeastern margin of the Tibetan Plateau and figures importantly in testing previous models about the uplift of the Tibetan Plateau. Currently, the uplift history of the Qilian Shan is vigorously debated, with age estimates ranging from Paleocene to Pliocene (Tapponnier et al., 2001; Yin et al., 2002, 2008; Dupont-Nivet et al., 2004; Fang et al., 2007, 2013; Zheng et al., 2010; Zhuang et al., 2011, 2018; Bush et al., 2016; He et al., 2017, 2018; Wang et al., 2017; Nie et al., 2019). The deformation timing generally falls within three categories: late Miocene-Quaternary deformation (e.g., Tapponnier et al., 1990, 2001; Meyer et al., 1998); early-middle Miocene deformation (e.g., George et al., 2001; Wang et al., 2003; Zheng et al., 2010); deformation synchronous with or slightly later than the India-Asia collision (e.g., Yin et al., 2002, 2008; Dai et al., 2005; He et al., 2017, 2018).

In this study, we report new apatite (U-Th)/He ages from five granite samples, four of which are along an altitude transect that spans $520 \mathrm{~m}$ of relief in the southern Qilian Shan, where no such dataset has been reported. The apatite (U-Th)/He thermochronology system has a lower closure temperature $\left(\sim 70{ }^{\circ} \mathrm{C}\right)$ than other thermochronology techniques and is 
sensitive to thermal perturbations (caused by either erosion or tectonic movements) of $\sim 2-3$ km beneath the surface of the Earth (Ehlers and Farley, 2003).

\section{Geologic setting}

The 500 km-wide Qilian Shan is a middle Paleozoic suture belt bounded by the Qaidam Basin to the south and the Alashan massif to the north (Tapponnier et al., 1990). It is composed of lower Paleozoic rocks that record rifting and closure of past ocean floors (Xu et al., 1996). The Qilian Shan can be divided into three blocks: the South Qilian block, Central Qilian block, and North Qilian block (Figure 1; Yin and Harrison, 2000).

The Qaidam Shan, the research target of this study (Figure 1), is located in the southernmost Qilian Shan and bounded to the south by the south-verging Qaidam Shan thrust (Yin et al., 2008). The Qaidam Shan consists of imbricate thrusts that placed Precambrian gneiss over Jurassic strata, which are underlain by Quaternary deposits (Figure 2). Granite plutons, dated to the early Paleozoic (ca. 435-456 Ma; Wu et al., 2002), crop out widely within the Qaidam Shan (QBGMR, 1991).

\section{Sampling}

In this study, fresh Paleozoic granites without quartz and calcite veins were collected in order to clarify the tectonic history of this region. Four samples were collected from an altitude transect on the hanging wall of the Qaidam Shan thrust. In addition, another sample was collected from $20 \mathrm{~km}$ northwest of the altitude transect at a lower elevation.

To separate apatite grains, all samples were crushed and sieved using standard mineral separation techniques. Minerals were separated by their magnetic susceptibility and density differences. Apatite grains were hand-picked and then examined for inclusions of high $U$ or Th phases under a binocular microscope using cross-polarized light. The grain dimensions were measured for alpha-ejection corrections (Farley et al., 1996, 2000). For each sample, at least three euhedral and clear apatite grains were picked, sealed in platinum tubes, and heated 
with a laser in a vacuum system to release helium, following the standard procedure in the thermochronology laboratory at the University of Texas at Austin (House et al., 2000; Nie et al., 2018). After removal from the vacuum system, grains were dissolved and analyzed in a Finnigan Element inductively couple plasma mass spectrometer (ICP-MS).

\section{Results}

All five samples from the Qaidam Shan yield Miocene apatite (U-Th)/He ages, with mean ages ranging from $15.0 \pm 2.6 \mathrm{Ma}$ to $9.6 \pm 2.4 \mathrm{Ma}$ (two sigma uncertainties; Table 1 ; Figure 3). These ages are significantly younger than their Paleozoic crystallization ages $(\mathrm{Wu}$ et al., 2002). Most of the samples yield relatively small age dispersion. Sample QFT-53 shows scattered apatite $(\mathrm{U}-\mathrm{Th}) / \mathrm{He}$ ages varying from $6.5 \pm 0.4 \mathrm{Ma}$ to $14.0 \pm 0.8 \mathrm{Ma}$ with a mean age of $13.1 \pm 0.9$ Ma. Sample QFT-55 has ages from 8.0 $\pm 0.5 \mathrm{Ma}$ to $11.8 \pm 0.7 \mathrm{Ma}$ with a mean age of 9.6 \pm 2.4 Ma. Sample QFT-58 has ages from $12.5 \pm 0.8$ Ma to $16.8 \pm 1.0$ Ma with a mean age of 15.0 $\pm 2.6 \mathrm{Ma}$. Sample QFT-62 has ages from $12.1 \pm 0.7$ Ma to $13.8 \pm$ 0.8 Ma with a mean age of $12.9 \pm 1.0 \mathrm{Ma}$. Sample QFT-65 shows a slightly large scatter of apatite $(\mathrm{U}-\mathrm{Th}) / \mathrm{He}$ ages ranging from $12.6 \pm 0.8 \mathrm{Ma}$ to $22.0 \pm 1.3 \mathrm{Ma}$ with a mean age of 13.3 $\pm 1.9 \mathrm{Ma}$.

To more clearly understand the thermal history of these samples, inverse modeling was applied to the thermochronology altitude transect employed the QTQt program using a Bayesian transdimensional Markov chain Monte Carlo protocol (Gallagher, 2012). The protocol used the radiation damage accumulation/annealing model of Flowers (Flowers et al., 2009) for helium diffusion in apatite. We used the following constraints during inverse modeling (Vermeesch and Tian, 2014). (1) The current surface temperature was set to $10 \pm$ $10{ }^{\circ} \mathrm{C}$. (2) The paleotemperature offsets were set to $10.4 \pm 10.4{ }^{\circ} \mathrm{C}$, which was calculated by multiplying their elevation difference by the present mean geothermal gradient $\left(20^{\circ} \mathrm{C} / \mathrm{km}\right.$; Zhuang et al., 2018). (3) Present-day temperature offsets between the uppermost and 
lowermost samples were set to $\sim 3 \pm 3{ }^{\circ} \mathrm{C}$, which was obtained by multiplying their elevation difference by a lapse rate of $\sim 6{ }^{\circ} \mathrm{C} / \mathrm{km}$. (4) The initial constraint box was set to $190 \pm 40{ }^{\circ} \mathrm{C}$ at $120 \pm 20 \mathrm{Ma}$ according to the zircon (U-Th)/He ages from the same study area (Zhuang et al., 2018). (5) Another constraint box was set to $110 \pm 20{ }^{\circ} \mathrm{C}$ at $15 \pm 5 \mathrm{Ma}$ according to the apatite fission track ages from the same study area (Zhuang et al., 2018). For the transect, 0.5 million iterations were run to derive stable inverse model results, as presented in Figure 4. The modeled apatite (U-Th)/He ages are generally consistent with the observed ages (Figure 4). The modeling results show that the Qaidam Shan experienced slow cooling from the Late Cretaceous to the early Miocene, and the cooling then accelerated rapidly at $15 \mathrm{Ma}$. After this rapid cooling, the Qaidam Shan cooled at moderate rates until the present (Figure 4). Such a thermal history is generally consistent with our thermochronological observations (Figure 3A).

\section{Discussion}

The four studied altitude transect samples, spanning $\sim 520 \mathrm{~m}$ of relief, are within a horizontal distance of $<1 \mathrm{~km}$. Interestingly, they have consistent cooling ages ranging from 15-10 Ma (Figure 3A), suggesting rapid exhumation of at least $520 \mathrm{~m}$ in elevation during the middle-late Miocene, consistent with the results of the inverse modeling (Figure 4). This exhumation can be achieved by top-down erosion driven by climatic changes, as is likely the case for formation of the Mekong River (Nie et al., 2018); alternatively, thrusting can cause rapid exhumation of these rocks from a bottom-up pattern.

Regional climate records reveal that climate changes are unlikely to have played a main role in causing the rapid exhumation observed here. First, different lines of evidence from northeastern Tibet suggest that arid conditions in this region began in the Oligocene or early- 
middle Miocene, attributed to the retreat of the Paratethys epicontinental sea, global cooling, or blocking of ocean moisture associated with uplift of northeastern Tibet (Wang et al., 2003; Graham et al., 2005; Dupont-Nivet et al., 2007; Kent-Corson et al., 2009; Zhuang et al., 2011; Hough et al., 2014; Li et al., 2016). It would be hard for the small magnitude of precipitation in this arid climate to cause more than $520 \mathrm{~m}$ of erosion in a short period. Second, it is widely accepted that the climate after 14 Ma corresponds to a period of weaker East Asian summer monsoons and decreased precipitation in comparison with the preceding middle Miocene climate optimum period ( 17-14 Ma) (Nie et al., 2018). If the precipitation increase is the forcing for rapid exhumation here, rapid cooling should have occurred during 17-14 Ma instead of the following late Miocene. Third, an apatite (U-Th)/He age transect located $\sim 20$ $\mathrm{km}$ northwest of our transect has age range of 25-10 Ma (Zhuang et al., 2018; Figure 2, Figure 3B), which have similar elevation but different age range compared with our transect. The climate conditions within a $20 \mathrm{~km}$ distance in the same geomorphological setting cannot differ enough to cause the observed different apatite (U-Th)/He ages.

Therefore, we attribute the rapid exhumation to a phase of thrusting bounding these rocks, which raised the rocks more than $520 \mathrm{~m}$ and caused the observed consistent middlelate Miocene cooling ages in the altitude transect samples. We note that one sample (QFT-65) at a lower elevation within a distance of $20 \mathrm{~km}$ to the northwest also shows a similar apatite (U-Th)/He age. This age was merged with published apatite (U-Th)/He ages sampled in the same area bounded by the same faults (Zhuang et al., 2018) in an age-elevation plot (Figure 2, Figure 3B). The lower elevation samples in this merged altitude transect generally show ages in the middle-late Miocene, generally similar but slightly older than the cooling event detected in our new transect (Figure 3). These ages suggest that thrusting migrated quickly from north to south during the middle-late Miocene. 
The inferred timing for rapid exhumation and uplift of the granite belts where the study samples were collected is consistent with stratigraphic records right in front of (south of) this part of the southern Qilian Shan. Bush et al. (2016) recorded the exhumation of this granite belt from the Dahonggou section at $\sim 3700 \mathrm{~m}$, according to new paleomagnetic dating (Nie et al., 2019), which corresponds to between 12.5 Ma and 10.6 Ma, consistent with the rapid cooling age range of samples directly from this granite belt. This consistency convincingly demonstrates that southward growth of the Qilian Shan occurred during the late Miocene period. Nie et al. (2019) also demonstrated that the initial appearance of the Qilian Shan signal occurred at $20 \mathrm{Ma}$, suggesting that the uplift of the Qilian Shan was significantly delayed in comparison with the India-Asia collision. The age for sediment accumulation initiation in the Dahonggou section reported by Nie et al. (2019) is similar to that in other sites of the northern Qaidam Basin (Fang et al., 2007; Wang et al., 2017), opening the possibility that the northern Qaidam Basin did not receive sediment until after $225-20$ Ma. These results, together with our new dataset, challenge models predicting an early Cenozoic uplift and deformation of the northeastern margin of the Tibetan Plateau (Yin et al., 2008; Dayem et al., 2009; Clark et al., 2010; Fang et al., 2013, 2019).

Other stratigraphic and sedimentologic evidence also supports that the northeastern Tibetan Plateau experienced rapid deformation and exhumation at 15-10 Ma (Figure 5). For example, in the northern Qaidam Basin, growth strata and intensified crustal shortening developed in the middle-late Miocene (Zhou et al., 2006; Yin et al., 2008), surface uplift occurred during 15-10 Ma (Zhuang et al., 2014), and a rapid increase in the accumulation rate occurred at 15-12 Ma (Fang et al., 2007). In the Jiuquan Basin, a change in sedimentary provenance and sedimentary facies accompanied by a rapid increase in sedimentation rate and the development of growth strata occurred at 14-10 Ma (Fang et al., 2013; Wang et al., 2016). In the Guide Basin, Yan et al. (2006) identified a clockwise rotation that took place 
during 17-11 Ma. In the Linxia Basin, $\mathrm{Nd}$ isotopes, trace elements and oxygen isotope data demonstrate increased unroofing of the northeastern margin of the Tibetan Plateau at $\sim 12 \mathrm{Ma}$ (Dettman et al., 2003; Garzione et al., 2005).

Other bedrock thermochronological records from the northeastern Tibetan Plateau are also consistent with evidence of rapid rock cooling during the middle-late Miocene (Figure 5). For example, Pang et al. (2019) and Yu et al. (2019) identified a rapid exhumation event in the southern Qilian Shan at 15-10 Ma. Zheng et al. (2010), Zhuang et al. (2018), and Li et al. (2019) revealed rapid exhumation of the northern Qilian Shan at 15-10 Ma. Lease et al. (2011) observed rapid exhumation of the Jishi Shan at 13 Ma.

\section{Conclusions}

We provide apatite (U-Th)/He age data from an altitude transect with more than $520 \mathrm{~m}$ of relief from the southern Qilian Shan. These data demonstrate rapid upper crustal exhumation in the southern Qilian Shan during 15-10 Ma. This phase of exhumation is broadly consistent with intensified tectonic deformation in the northeastern Tibetan Plateau during the middle-late Miocene, challenging tectonic models arguing for early deformation of the northeastern Tibetan Plateau.

\section{Acknowledgement}

This work was co-supported by the Second Tibetan Plateau Scientific Expedition and Research (STEP) (grant 2019QZKK0707), the Strategic Priority Research Program of Chinese Academy of Sciences (grant XDA2007020102), and the National Natural Science Foundation of China (grants 41872098 and 41902223). We thank Zhiguo Zhang for sample analyses in the lab. Critical reviews from editor Zheng-Xiang $\mathrm{Li}$ and two anonymous reviewers are thanked. 


\section{References}

Besse, J., Courtillot, V., Pozzi, J.P., Westphal, M., Zhou, Y., 1984. Palaeomagnetic estimates of crustal shortening in the Himalayan thrusts and Zangbo suture. Nature 311(5987), 621-626. doi:10.1038/311621a0

Burchfiel, B.C., Zhang, P., Wang, Y., Zhang, W., Song, F., Deng, Q., Royden, L., 1991. Geology of the Haiyuan fault zone, Ningxia-Hui Autonomous Region, China, and its relation to the evolution of the northeastern margin of the Tibetan Plateau. Tectonics 10(6), 1091-1110. doi:10.1029/90TC02685

Bush, M.A., Saylor, J.E., Horton, B.K., Nie, J., 2016. Growth of the Qaidam Basin during Cenozoic exhumation in the Northern Tibetan Plateau: Inferences from depositional patterns and multiproxy detrital provenance signatures. Lithosphere 8(1), 58-82. doi:10.1130/L449.1

Clark, M.K., Farley, K.A., Zheng, D., Wang, Z., Duvall, A.R., 2010. Early Cenozoic faulting of the northern Tibetan Plateau margin from apatite (U-Th)/He ages. Earth and Planetary Science Letters 296(1-2), 78-88. doi:10.1016/j.eps1.2010.04.051

Dai, S., Fang, X., Song, C., Gao, J., Gao, D., Li, J., 2005. Early tectonic uplift of the northern Tibetan Plateau. Chinese Science Bulletin 50(15), 1642-1652. doi:10.1360/03wd0255

Dayem, K.E., Molnar, P., Clark, M.K., Houseman, G.A., 2009. Far-field lithospheric deformation in Tibet during continental collision. Tectonics 28(6), 1-9. doi:10.1029/2008tc002344

Dettman, D.L., Fang, X., Garzione, C.N., Li, J., 2003. Uplift-driven climate change at 12 Ma: a long ${ }^{18} \mathrm{O}$ record from the NE margin of the Tibetan plateau. Earth and Planetary Science Letters 214(1), 267-277. doi:10.1016/S0012-821X(03)00383-2

DeCelles, P.G., Kapp, P., Gehrels, G.E., Ding, L., 2014. Paleocene-Eocene foreland basin evolution in the Himalaya of southern Tibet and Nepal: Implications for the age of initial India-Asia collision. Tectonics 33(5), 824-849. doi:10.1002/2014tc003522

Dupont-Nivet, G., Horton, B.K., Butler, R.F., Wang, J., Zhou, J., Waanders, G.L., 2004. Paleogene clockwise tectonic rotation of the Xining-Lanzhou region, northeastern Tibetan Plateau. Journal of Geophysical Research 109(B4), B04401. doi:10.1029/2003jb002620

Dupont-Nivet, G., Krijgsman, W., Langereis, C.G., Abels, H.A., Dai, S., Fang, X., 2007. Tibetan plateau aridification linked to global cooling at the Eocene-Oligocene transition. Nature 445(7128), 635-638. doi:10.1038/nature05516

Duvall, A.R., Clark, M.K., Kirby, E., Farley, K.A., Craddock, W.H., Li, C., Yuan, D.Y., 2013. Low-temperature thermochronometry along the Kunlun and Haiyuan Faults, NE Tibetan Plateau: Evidence for kinematic change during late-stage orogenesis. Tectonics 32(5), 1190-1211. doi:10.1002/tect.20072

Ehlers, T.A., Farley, K.A., 2003. Apatite (U-Th)/He thermochronometry: methods and applications to problems in tectonic and surface processes. Earth and Planetary Science Letters 206(1-2), 1-14. doi:10.1016/s0012$821 \times(02) 01069-5$

Fang, X., Fang, Y., Zan, J., Zhang, W., Song, C., Appel, E., Meng, Q., Miao, Y., Dai, S., Lu, Y., Zhang, T., 2019. Cenozoic magnetostratigraphy of the Xining Basin, NE Tibetan Plateau, and its constraints on paleontological, sedimentological and tectonomorphological evolution. Earth-Science Reviews 190, 460-485. 
doi:10.1016/j.earscirev.2019.01.021

Fang, X., Liu, D., Song, C., Dai, S., Meng, Q., 2013. Oligocene slow and Miocene-Quaternary rapid deformation and uplift of the Yumu Shan and North Qilian Shan: evidence from high-resolution magnetostratigraphy and tectonosedimentology. Geological Society, London, Special Publications 373(1), 149-171. doi:10.1144/sp373.5

Fang, X., Zhang, W., Meng, Q., Gao, J., Wang, X., King, J., Miao, Y., 2007. High-resolution magnetostratigraphy of the Neogene Huaitoutala section in the eastern Qaidam Basin on the NE Tibetan Plateau, Qinghai Province, China and its implication on tectonic uplift of the NE Tibetan Plateau. Earth and Planetary Science Letters 258(1-2), 293-306. doi:10.1016/j.epsl.2007.03.042

Farley, K.A., 2000. Helium diffusion from apatite: General behavior as illustrated by Durango fluorapatite. Journal of Geophysical Research: Solid Earth 105(B2), 2903-2914. doi:10.1029/1999jb900348

Farley, K.A., Wolf, R.A., Silver, L.T., 1996. The effects of long alpha-stopping distances on (U-Th)/He ages. Geochimica et Cosmochimica Acta 60(21), 4223-4229. doi:10.1016/s0016-7037(96)00193-7

Flowers R.M., Ketcham R.A., Shuster D.L., Farley, K.A., 2009. Apatite (U-Th)/He thermochronometry using a radiation damage accumulation and annealing model. Geochimica et Cosmochimica Acta 73(8), 2347-2365. doi:10.1016/j.gca.2009.01.015

Gallagher, K., 2012. Transdimensional inverse thermal history modeling for quantitative thermochronology. Journal of Geophysical Research: Solid Earth 117(B2). doi:10.1029/2011JB008825

Garzione, C.N., Ikari, M.J., Basu, A.R., 2005. Source of Oligocene to Pliocene sedimentary rocks in the Linxia basin in northeastern Tibet from Nd isotopes: Implications for tectonic forcing of climate. Geological Society of America Bulletin 117(9), 1156-1166. doi:10.1130/b25743.1

George, A.D., Marshallsea, S.J., Wyrwoll, K.H., Chen, J., Lu, Y., 2001. Miocene cooling in the northern Qilian Shan, northeastern margin of the Tibetan Plateau, revealed by apatite fission-track and vitrinite-reflectance analysis. Geology 29(10), 939-942. doi:10.1130/0091-7613(2001)029<0939:MCITNQ>2.0.CO;2

Graham, S.A., Chamberlain, C.P., Yue, Y., Ritts, B.D., Hanson, A.D., Horton, T.W., Feng, X., 2005. Stable isotope records of Cenozoic climate and topography, Tibetan plateau and Tarim basin. American Journal of Science 305(2), 101-118. doi:10.2475/ajs.305.2.101

He, P., Song, C., Wang, Y., Chen, L., Chang, P., Wang, Q., Ren, B., 2017. Cenozoic exhumation in the Qilian Shan, northeastern Tibetan Plateau: Evidence from detrital fission track thermochronology in the Jiuquan Basin. Journal of Geophysical Research: Solid Earth 122(8), 6910-6927. doi:10.1002/2017jb014216

He, P., Song, C., Wang, Y., Meng, Q., Chen, L., Yao, L., Huang, R., Feng, W., Chen, S., 2018. Cenozoic deformation history of the Qilian Shan (northeastern Tibetan Plateau) constrained by detrital apatite fissiontrack thermochronology in the northeastern Qaidam Basin. Tectonophysics 749, 1-11. doi:10.1016/j.tecto.2018.10.017

Hough, B.G., Garzione, C.N., Wang, Z., Lease, R.O., 2014. Timing and spatial patterns of basin segmentation and climate change in northeastern Tibet. Geological Society of America Special Papers 507, 129-153. doi:10.1130/2014.2507(07)

House, M.A., Farley, K.A., Stockli, D., 2000. Helium chronometry of apatite and titanite using Nd-YAG laser 
heating. Earth and Planetary Science Letters 183(3-4), 365-368. doi:10.1016/s0012-821x(00)00286-7

Hu, X., Garzanti, E., Wang, J., Huang, W., An, W., Webb, A., 2016. The timing of India-Asia collision onsetFacts, theories, controversies. Earth Science Reviews 160, 264-299. doi:10.1016/j.earscirev.2016.07.014

Kent-Corson, M.L., Ritts, B.D., Zhuang, G., Bovet, P.M., Graham, S.A., Chamberlain, C.P., 2009. Stable isotopic constraints on the tectonic, topographic, and climatic evolution of the northern margin of the Tibetan Plateau. Earth and Planetary Science Letters 282(1-4), 158-166. doi:10.1016/j.eps1.2009.03.011

Lease, R.O., Burbank, D.W., Clark, M.K., Farley, K.A., Zheng, D., Zhang, H., 2011. Middle Miocene reorganization of deformation along the northeastern Tibetan Plateau. Geology 39(4), 359-362. doi: $10.1130 / \mathrm{g} 31356.1$

Li, B., Chen, X., Zuza, A.V., Hu, D., Ding, W., Huang, P., Xu, S., 2019. Cenozoic cooling history of the North Qilian Shan, northern Tibetan Plateau, and the initiation of the Haiyuan fault: Constraints from apatite- and zircon-fission track thermochronology. Tectonophysics 751, 109-124. doi:10.1016/j.tecto.2018.12.005

Li, J., Fang, X., Song, C., Pan, B., Ma, Y., Yan, M., 2014. Late Miocene-Quaternary rapid stepwise uplift of the NE Tibetan Plateau and its effects on climatic and environmental changes. Quaternary Research 81(03), 400423. doi:10.1016/j.yqres.2014.01.002

Li, L., Garzione, C.N., Pullen, A., Chang, H., 2016. Early-middle Miocene topographic growth of the northern Tibetan Plateau: Stable isotope and sedimentation evidence from the southwestern Qaidam basin. Palaeogeography, Palaeoclimatology, Palaeoecology 461, 201-213. doi:10.1016/j.palaeo.2016.08.025

Meyer, B., Tapponnier, P., Bourjot, L., Metivier, F., Gaudemer, Y., Peltzer, G., Chen, Z., 1998. Crustal thickening in Gansu-Qinghai, lithospheric mantle subduction, and oblique, strike-slip controlled growth of the Tibet plateau. Geophysical Journal International 135(1), 1-47. doi:10.1046/j.1365-246x.1998.00567.x

Nie, J., Ruetenik, G., Gallagher, K., Hoke, G., Garzione, C.N., Wang, W., Stockli, D., Hu, X., Wang, Z., Wang, Y., Stevens, T., Danišík, M., Liu, S., 2018. Rapid incision of the Mekong River in the middle Miocene linked to monsoonal precipitation. Nature Geoscience 11(12), 944. doi: 10.1038/s41561-018-0244-Z

Nie, J., Ren, X., Saylor, J.E., Su, Q., Horton, B.K., Bush, M.A., Chen, W., Pfaff, K., 2019. Magnetic polarity stratigraphy, provenance, and paleoclimate analysis of Cenozoic strata in the Qaidam Basin, NE Tibetan Plateau. Geological Society of America Bulletin. doi:10.1130/b35175.1 .

Pang, J., Yu, J., Zheng, D., Wang, W., Ma, Y., Wang, Y., Li, C., Li, Y., Wang, Y., 2019. Neogene Expansion of the Qilian Shan, North Tibet: Implications for the Dynamic Evolution of the Tibetan Plateau. Tectonics 38(3), 1018-1032. doi:10.1029/2018tc005258

Patriat, P., Achache, J., 1984. India-Eurasia collision chronology had implications for crustal shortening and driving mechanism of plates nature. Nature 311(5987), 615-621. doi:10.1038/311615a0

QBGMR (Qinghai Bureau of Geology and Mineral Resource), 1991. Regional geology of Qinghai province. Geological Publishing House, Beijing. (in Chinese with English abstract)

Rowley, D.B., 1996. Age of initiation of collision between India and Asia: A review of stratigraphic data. Earth and Planetary Science Letters 145(1-4), 1-13. doi:10.1016/s0012-821x(96)00201-4

Tapponnier, P., 2001. Oblique Stepwise Rise and Growth of the Tibet Plateau. Science 294(5547), 1671-1677. doi:10.1126/science. 105978 
Tapponnier, P., Meyer, B., Avouac, J.P., Peltzer, G., Gaudemer, Y., Guo, S., Xiang, H., Yin, K., Chen, Z., Cai, S., Dai, H., 1990. Active thrusting and folding in the Qilian Shan, and decoupling between upper crust and mantle in northeastern Tibet. Earth and Planetary Science Letters 97(3-4), 382-403. doi:10.1016/0012$821 \times(90) 90053-\mathrm{z}$

Vermeesch, P., Tian, Y.T., 2014. Thermal history modelling: HeFTy vs. QTQt. Earth-Science Reviews 139, 279-290. doi:10.1016/j.earscirev.2014.09.010

Wang, W., Zhang, P., Pang, J., Garzione, C., Zhang, H., Liu, C., Zheng, D., Zheng, W., Yu, J., 2016. The Cenozoic growth of the Qilian Shan in the northeastern Tibetan Plateau: A sedimentary archive from the Jiuxi Basin. Journal of Geophysical Research: Solid Earth 121(4), 2235-2257. doi:10.1002/2015JB012689

Wang, W., Zheng, W., Zhang, P., Li, Q., Kirby, E., Yuan, D., Zheng, D., Liu, C., Wang, Z., Zhang, H., Pang, J., 2017. Expansion of the Tibetan plateau during the Neogene. Nature Communications 8, 15887, doi:10.1038/ncomms15887.

Wang, X., Wang, B., Qiu, Z., Xie, G., Xie, J., Downs, W., Deng, T., 2003. Danghe area (western Gansu, China) biostratigraphy and implications for depositional history and tectonics of northern Tibetan Plateau. Earth and Planetary Science Letters 208(3-4), 253-269. doi:10.1016/s0012-821x(03)00047-5

Wu, C., Yang, J., Wooden, J., Liou, J.G., Li, H., Shi, R., Meng, F., Persing, H., Meibom, H., 2002. Zircon SHRIMP dating of granite from Qaidamshan, NW China. Chinese Science Bulletin 47(5), 418-422. doi:10.1360/02tb9097

Wu, L., Lin, X.B., Cowgill, E., Xiao, A.C., Cheng, X.G., Chen, H.L., Zhao, H.F., Shen, Y., Yang, S.F., 2019. Middle Miocene reorganization of the Altyn Tagh fault system, northern Tibetan Plateau. Geological Society of America Bulletin 131(7-8), 1157-1178. doi:10.1130/B31875.1

Xiao, W., Windley, B.F., Yong, Y., Yan, Z., Yuan, C., Liu, C., Li, J., 2009. Early Paleozoic to Devonian multiple-accretionary model for the Qilian Shan, NW China. Journal of Asian Earth Sciences 35(3-4), 323333. doi:10.1016/j.jseaes.2008.10.001

Xu, Z., Cui, J., Zhang, J., 1996. Deformation Dynamics of Continental Mountain Chains. Metallurgical Industry Press, Beijing. (in Chinese)

Yan, M., VanderVoo, R., Fang, X.., Parés, J.M., Rea, D.K., 2006. Paleomagnetic evidence for a mid-Miocene clockwise rotation of about $25^{\circ}$ of the Guide Basin area in NE Tibet. Earth and Planetary Science Letters 241(1-2), 234-247. doi:10.1016/j.eps1.2005.10.013

Yin, A., Harrison, T.M., 2000. Geologic evolution of the Himalayan-Tibetan orogen. Annual Review of Earth and Planetary Sciences 28(1), 211-280. doi:10.1146/annurev.earth.28.1.211

Yin, A., Dang, Y., Wang, L., Jiang, W., Zhou, S., Chen, X., McRivette, M.W., 2008. Cenozoic tectonic evolution of Qaidam basin and its surrounding regions (Part 1): The southern Qilian Shan-Nan Shan thrust belt and northern Qaidam basin. Geological Society of America Bulletin 120(7-8), 813-846. doi:10.1130/b26180.1

Yin, A., Rumelhart, P.E., Butler, R., Cowgill, E., Harrison, T.M., Foster, D.A., Hanson, A., 2002. Tectonic history of the Altyn Tagh fault system in northern Tibet inferred from Cenozoic sedimentation. Geological Society of America Bulletin 114(10), 1257-1295. doi:10.1130/0016-7606(2002)114<1257:thotat>2.0.co;2 
Yu, J., Zheng, D., Pang, J., Wang, Y., Fox, M., Vermeesch, P., Li, C., Xiao, L., Hao, Y., Wang, Y., 2019. Miocene range growth along the Altyn Tagh Fault: Insights from apatite fission track and (U-Th)/He thermochronometry in the western Danghenan Shan, China. Journal of Geophysical Research: Solid Earth 124. doi:10.1029/2019jb017570

Yuan, D., Ge, W., Chen, Z., Li, C., Wang, Z., Zhang, H., Zhang, P., Zheng, D., Zheng, W., Craddock, W.H., Dayem, K.E., Duvall, A.R., Brian G., Hough, B.G., Lease, R.O., Jean-Daniel Champagnac, J., Burbank, D.W., Clark, M.K., Farely, K.A., Carmala N., Garzione, C.N., Kirby, E., Molnar, P., Roe, G.H., 2013. The growth of northeastern Tibet and its relevance to large-scale continental geodynamics: a review of recent studies. Tectonics 32(5), 1358-1370. doi:10.1002/tect.20081

Zheng, D., Clark, M.K., Zhang, P., Zheng, W., Farley, K.A., 2010. Erosion, fault initiation and topographic growth of the North Qilian Shan (northern Tibetan Plateau). Geosphere 6(6), 937-941. doi:10.1130/ges00523.1

Zhou, J., Xu, F., Wang, T., Cao, A., Yin, C., 2006. Cenozoic deformation history of the Qaidam Basin, NW China: Results from cross-section restoration and implications for Qinghai-Tibet Plateau tectonics. Earth and Planetary Science Letters 243(1-2), 195-210. doi:10.1016/j.epsl.2005.11.033

Zhuang, G., Brandon, M.T., Pagani, M., Krishnan, S., 2014. Leaf wax stable isotopes from Northern Tibetan Plateau: Implications for uplift and climate since 15 Ma. Earth and Planetary Science Letters 390, 186-198. doi:10.1016/j.epsl.2014.01.003

Zhuang, G., Hourigan, J.K., Ritts, B.D., Kent-Corson, M.L., 2011. Cenozoic multiplephase tectonic evolution of the northern Tibetan Plateau: constraints from sedimentary records from Qaidam basin, Hexi Corridor, and Subei basin, northwest China. American Journal of Science 311(2), 116-152. doi:10.2475/02.2011.02

Zhuang, G., Johnstone, S.A., Hourigan, J., Ritts, B., Robinson, A., Sobel, E.R., 2018. Understanding the geologic evolution of Northern Tibetan Plateau with multiple thermochronometers. Gondwana Research 58, 195-210. doi:10.1016/j.gr.2018.02.014 
Table 1. Apatite (U-Th)/He ages and relevant information

\begin{tabular}{|c|c|c|c|c|c|c|c|c|c|c|c|c|}
\hline Sample & $\mathrm{U}(\mathrm{ppm})$ & Th (ppm) & $\begin{array}{l}\mathrm{He}\left(\times 10^{-6}\right. \\
\mathrm{nmol})\end{array}$ & {$[\mathrm{eU}]$} & $\begin{array}{l}\text { mass } \\
(\mu \mathrm{g})\end{array}$ & $\mathrm{Ft}$ & $\begin{array}{l}\text { Grain length } \\
(\mu \mathrm{m})\end{array}$ & $\begin{array}{l}\text { Grain width } \\
(\mu \mathrm{m})\end{array}$ & $\begin{array}{l}\text { ESR } \\
(\mu \mathrm{m})\end{array}$ & $\begin{array}{l}\text { Raw age } \\
\text { (Ma) }\end{array}$ & $\begin{array}{l}\text { Corrected } \\
\text { age (Ma) }\end{array}$ & $\pm \sigma$ \\
\hline QFT-53-1 & 4.0 & 0.2 & 0.664 & 4.3 & 3.19 & 0.71 & 177.7 & 94.4 & 49.8 & 8.6 & 12.1 & 0.7 \\
\hline QFT-53-2 & 2.9 & 0.7 & 1.190 & 3.3 & 5.89 & 0.77 & 181.2 & 127.1 & 63.3 & 10.8 & 14.0 & 0.8 \\
\hline \multirow[t]{2}{*}{ QFT-53-3 ${ }^{+}$} & 2.7 & 0.1 & 0.238 & 2.9 & 3.08 & 0.72 & 139.7 & 104.6 & 51.3 & 4.7 & 6.5 & 0.4 \\
\hline & & & \multicolumn{10}{|c|}{$37^{\circ} 46^{\prime} 19^{\prime \prime}(\mathrm{N}), 95^{\circ} 31^{\prime} 27^{\prime \prime}(\mathrm{E}), 4250 \mathrm{~m}$ (elevation) Mean age $(2 \sigma): 13.1(1.9) \mathrm{Ma}$} \\
\hline QFT-55-1 & 2.4 & 8.6 & 0.396 & 4.4 & 2.69 & 0.68 & 148.1 & 95.1 & 48.3 & 6.12 & 9.0 & 0.5 \\
\hline QFT-55-2 & 0.7 & 8.2 & 0.090 & 2.6 & 1.28 & 0.60 & 90.7 & 83.6 & 38.8 & 4.8 & 8.0 & 0.5 \\
\hline \multirow[t]{2}{*}{ QFT-55-3 } & 2.7 & 11.9 & 1.279 & 5.5 & 5.02 & 0.72 & 231.4 & 103.8 & 56.4 & 8.5 & 11.8 & 0.7 \\
\hline & & & \multicolumn{10}{|c|}{$37^{\circ} 46^{\prime} 25^{\prime \prime}(\mathrm{N}), 95^{\circ} 31^{\prime} 14^{\prime \prime}(\mathrm{E}), 4190 \mathrm{~m}$ (elevation) Mean age $(2 \sigma): 9.6(2.4) \mathrm{Ma}$} \\
\hline QFT-58-1 & 4.8 & 4.4 & 1.264 & 6.1 & 4.12 & 0.73 & 165.1 & 111.4 & 56.0 & 8.8 & 12.5 & 0.8 \\
\hline QFT-58-2 & 8.7 & 21.5 & 4.146 & 13.8 & 4.72 & 0.73 & 187.8 & 111.8 & 57.7 & 11.7 & 15.9 & 1.0 \\
\hline \multirow[t]{2}{*}{ QFT-58-3 } & 18.1 & 8.8 & 4.790 & 20.3 & 3.64 & 0.71 & 205.3 & 93.9 & 50.9 & 11.8 & 16.8 & 1.0 \\
\hline & & & \multicolumn{10}{|c|}{$37^{\circ} 46^{\prime} 43^{\prime \prime}(\mathrm{N}), 95^{\circ} 30^{\prime} 47^{\prime \prime}(\mathrm{E}), 3990 \mathrm{~m}$ (elevation) Mean age $(2 \sigma): 15.0$ (2.6) Ma } \\
\hline QFT-62-1 & 15.8 & 30.1 & 1.984 & 23.0 & 2.02 & 0.64 & 159.0 & 79.5 & 42.4 & 7.7 & 12.1 & 0.7 \\
\hline QFT-62-2 & 12.1 & 28.8 & 3.559 & 19.0 & 3.74 & 0.71 & 156.5 & 109.0 & 54.4 & 9.1 & 12.8 & 0.8 \\
\hline \multirow[t]{2}{*}{ QFT-62-3 } & 15.3 & 35.0 & 3.220 & 23.7 & 2.63 & 0.68 & 138.6 & 97.1 & 48.4 & 9.4 & 13.8 & 0.8 \\
\hline & & & \multicolumn{10}{|c|}{$37^{\circ} 47^{\prime} 16^{\prime \prime}(\mathrm{N}), 95^{\circ} 30^{\prime} 12^{\prime \prime}(\mathrm{E}), 3730 \mathrm{~m}$ (elevation) Mean age $(2 \sigma): 12.9(1.0) \mathrm{Ma}$} \\
\hline QFT-65-1 ${ }^{+}$ & 10.0 & 6.7 & 3.840 & 11.9 & 3.65 & 0.73 & 127.7 & 119.1 & 55.1 & 16.1 & 22.0 & 1.3 \\
\hline QFT-65-2 & 8.8 & 3.6 & 1.149 & 9.9 & 2.19 & 0.68 & 128.8 & 92.0 & 45.6 & 9.6 & 14.1 & 0.9 \\
\hline QFT-65-3 & 2.6 & 1.3 & 0.136 & 3.0 & 1.08 & 0.60 & 107.6 & 70.6 & 35.7 & 7.6 & 12.6 & 0.8 \\
\hline
\end{tabular}

${ }^{+}$labels replicate ages that are 50\% different from the other two replicates. In addition, the labeled ages are not used to calculate the mean ages of the samples. 


\section{Figure captions}

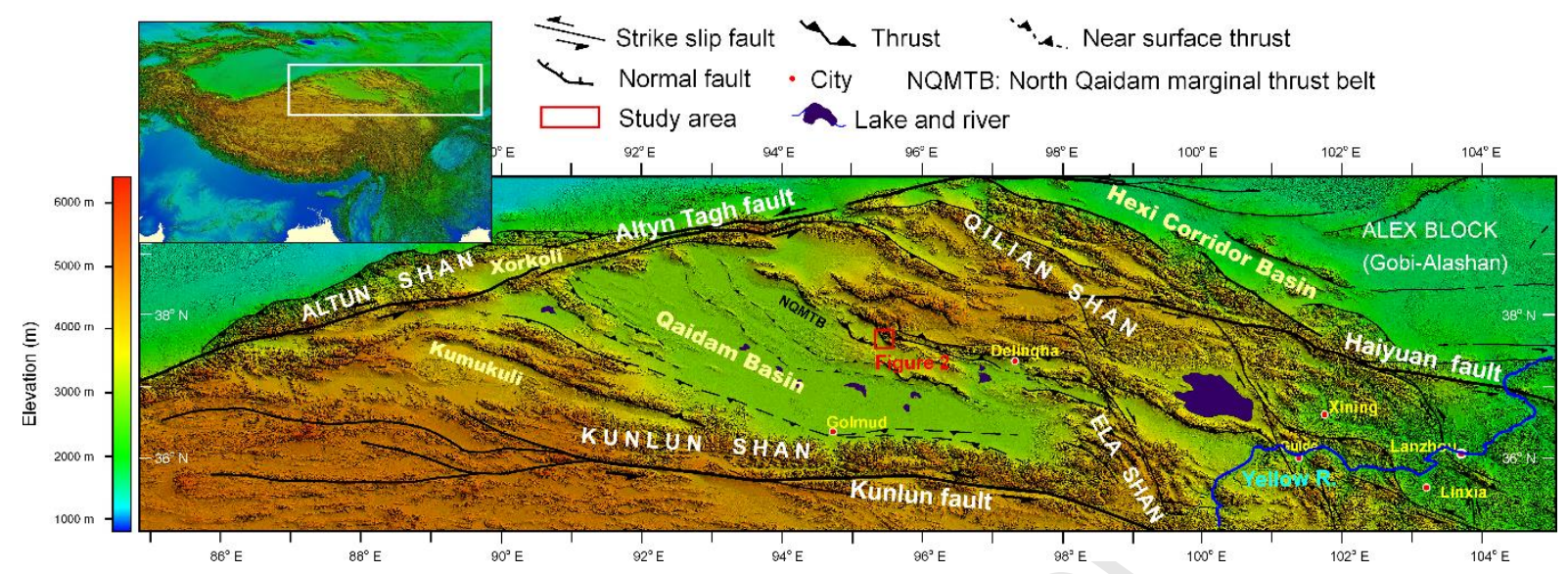

Figure 1. DEM plot of the northeastern Tibetan Plateau with major tectonic features highlighted (modified from Li et al., 2014). Figure 2 corresponds to the rectangle in this figure. (For interpretation of the references to color in this figure legend, the reader is referred to the web version of this article.) 

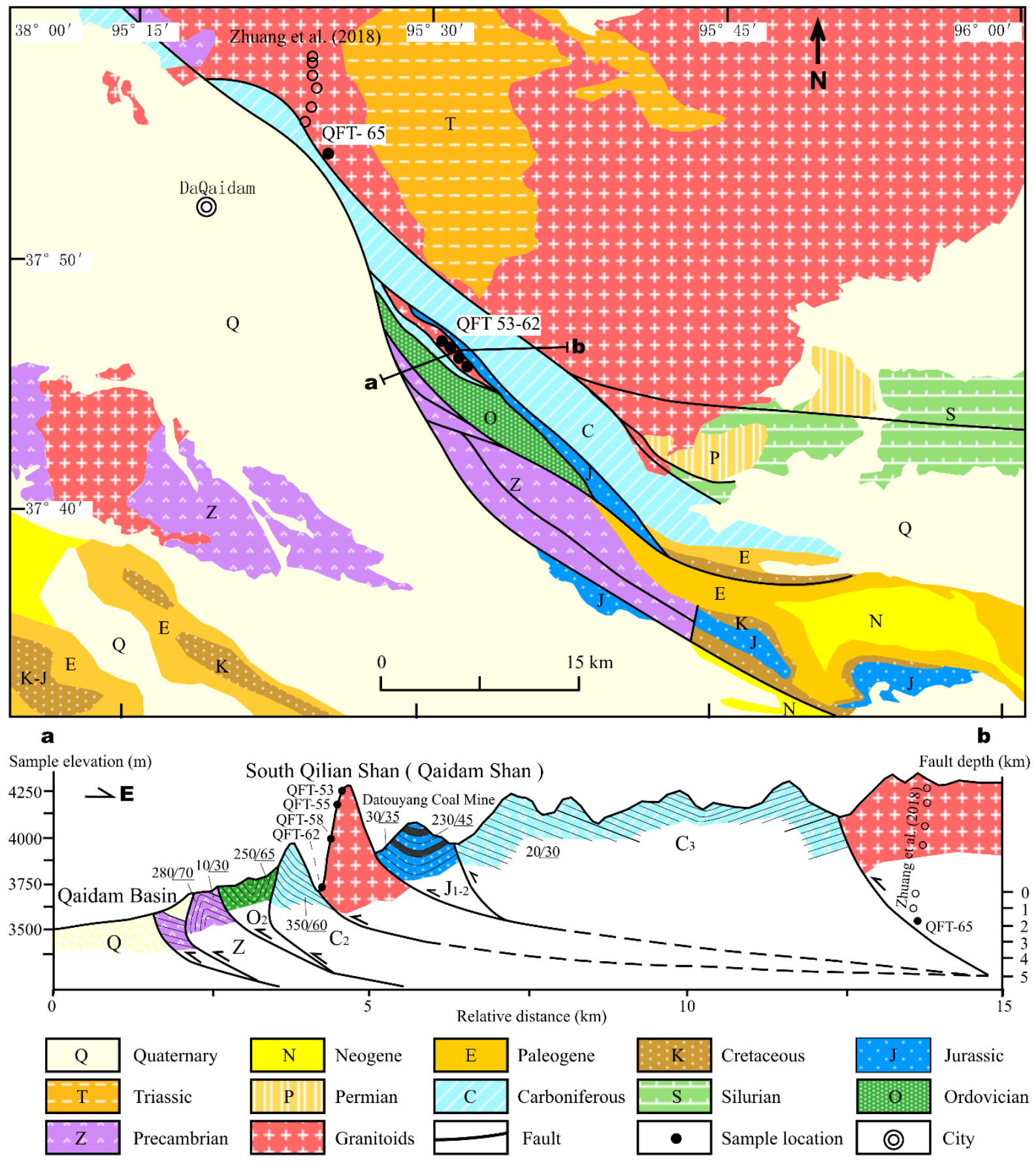

Figure 2. Simplified geologic map (modified from QBGMR, 1991) and cross section of the study area. The locations of the samples are represented. The fault depth parameters in the cross section are from Yin et al. (2008). (For interpretation of the references to color in this figure legend, the reader is referred to the web version of this article.) 

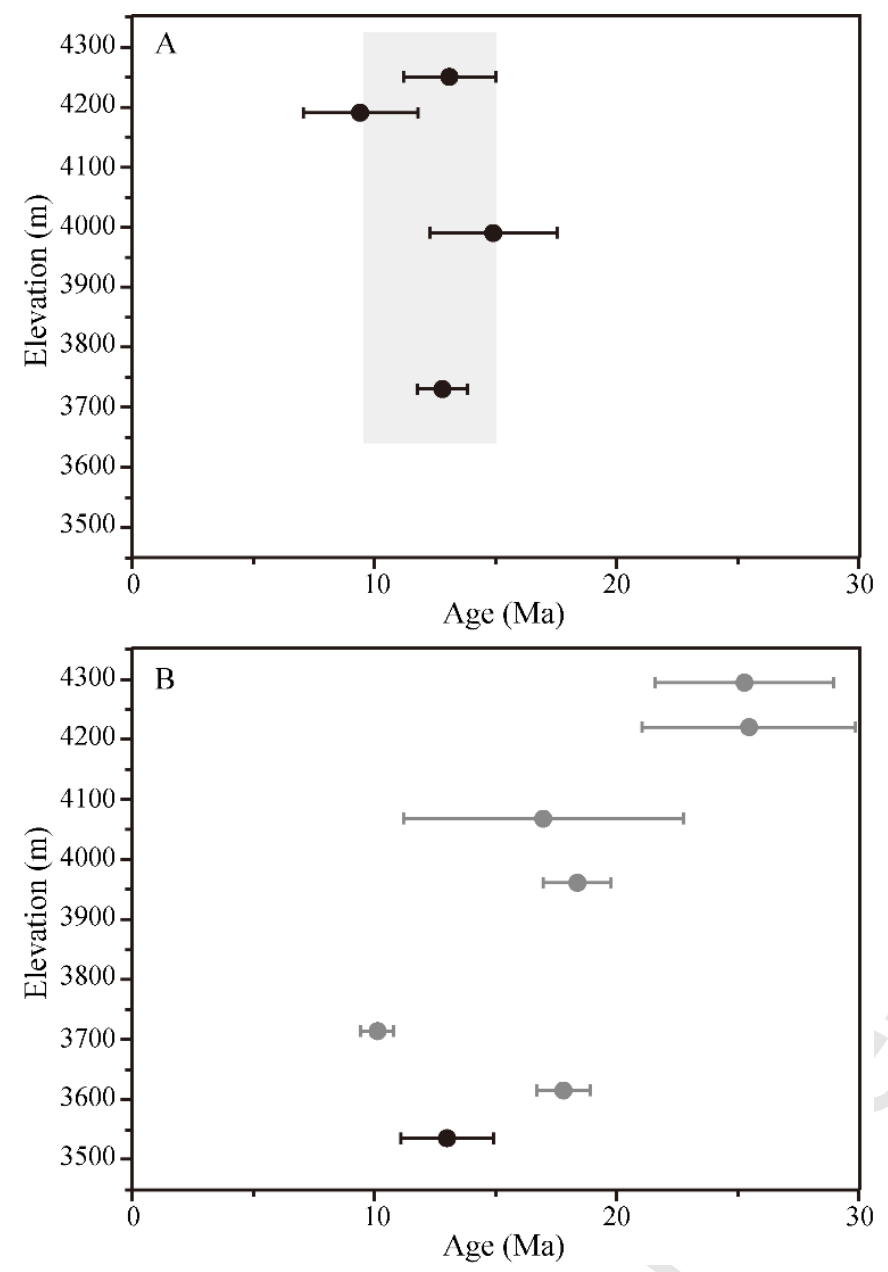

Figure 3. Age-elevation plots for apatite (U-Th)/He samples from the Qaidam Shan. Panel A represents the altitude transect with the mean ages of the samples in this study. Panel B represents an altitude transect with apatite $(\mathrm{U}-\mathrm{Th}) / \mathrm{He}$ ages that include the isolated sample in this study (QFT-65; black dots) and samples from Zhuang et al. (2018) (gray dots). Horizontal error bars represent $2 \sigma$ uncertainty on mean helium ages. 

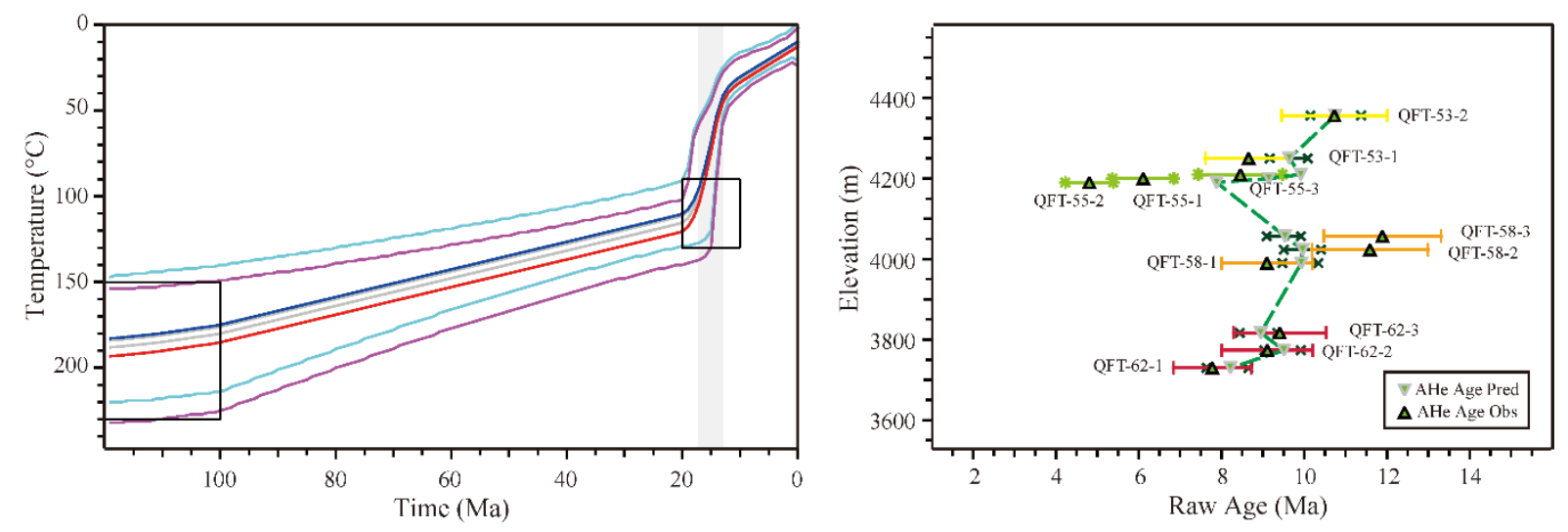

Figure 4. The expected thermal histories and mean age predictions for the altitude transect samples. Left: the expected thermal histories (thick blue and red lines) using the radiation damage models of Flowers (Flowers et al., 2009). The thermal history of the uppermost sample (QFT-53) is plotted in blue, the lowermost sample (QFT-62) in red, and intermediate samples in gray. The cyan and magenta lines are the $95 \%$ credible intervals of the coldest (blue line) and hottest (red line) sample thermal histories. Right: Comparison between observed and predicted single-grain uncorrected ages for this model. The raw observed values are shown as upward-pointing triangles with \pm 1 standard deviations, and the raw predicted values are shown as downward-pointing triangles with \pm 1 standard deviations. Error bars of different colors on the right side of the figure represent different samples. A small elevation perturbation was added so that older ages are slightly above the younger ages for a particular sample, in order to facilitate visualization. (For interpretation of the references to color in this figure legend, the reader is referred to the web version of this article.) 


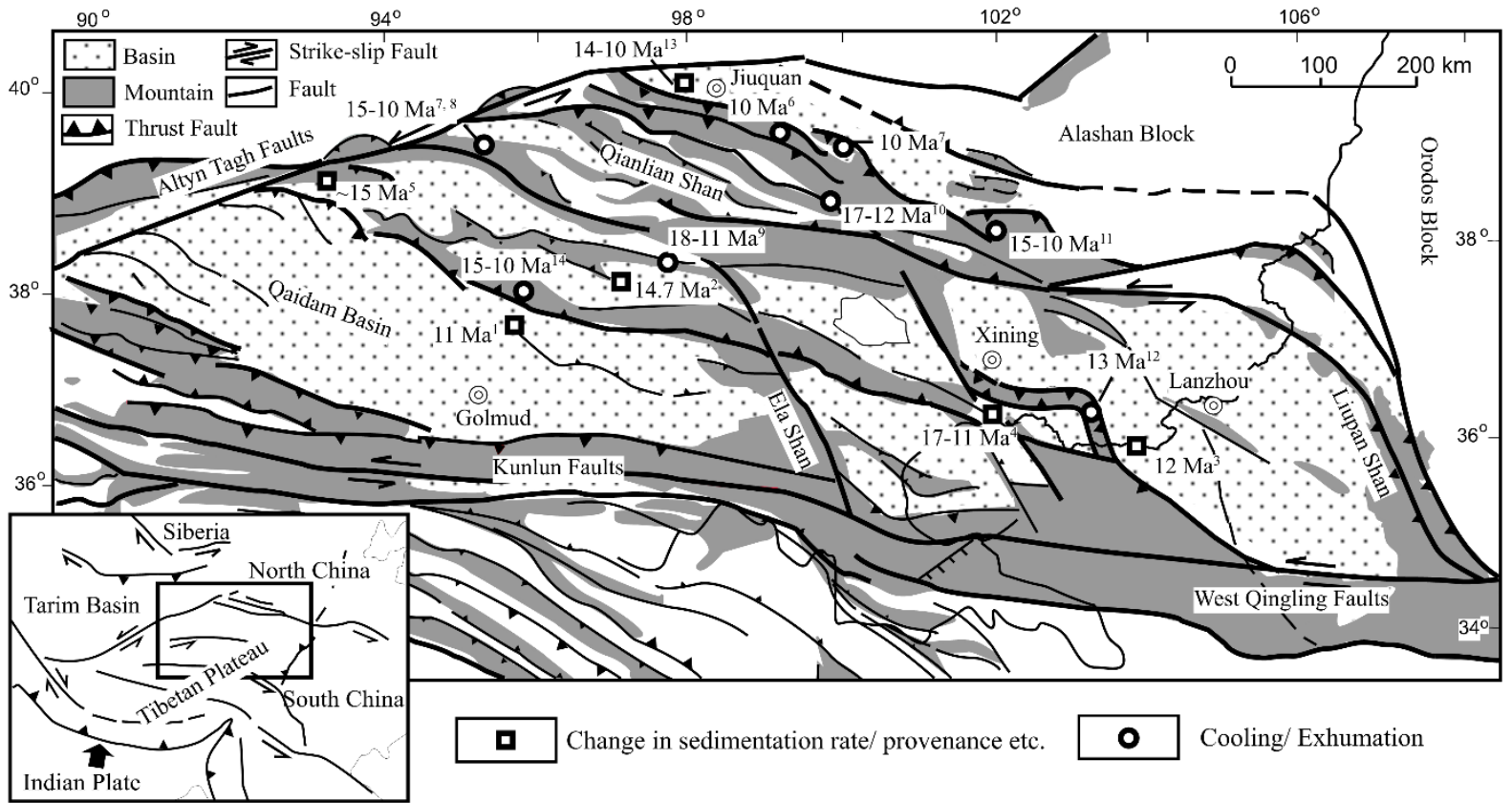

Figure 5. Evidence for the middle-late Miocene regional deformation in the northeastern Tibetan Plateau. ${ }^{1}$ Nie et al. (2019), ${ }^{2}$ Fang et al. (2007), ${ }^{3}$ Dettman et al. (2003), ${ }^{4}$ Yan et al. (2006), ${ }^{5} \mathrm{Wu}$ et al. (2019), ${ }^{6}$ Zheng et al. (2010), ${ }^{7}$ Zhuang et al. (2018), ${ }^{8} \mathrm{Yu}$ et al. (2019), ${ }^{9}$ Pang et al. (2019), ${ }^{10}$ Duvall et al. (2013), ${ }^{11} \mathrm{Li}$ et al. (2019), ${ }^{12}$ Lease et al. (2011), ${ }^{13} \mathrm{~W}$ ang et al. (2016), and ${ }^{14}$ This study. 


\section{Declaration of interests}

$\bigotimes$ The authors declare that they have no known competing financial interests or personal relationships that could have appeared to influence the work reported in this paper.

$\square$ The authors declare the following financial interests/personal relationships which may be

considered as potential competing interests: 
Highlights:

- We present apatite (U-Th)/He altitude transect ages from the southern Qilian Shan.

- The data reveal rapid exhumation of the southern Qilian Shan during 15-10 Ma.

- Regional deformation in the mid-late Miocene occurred in the NE Tibetan Plateau. 